\title{
南海トラフ巨大地震における静岡県沿岸域での 推定地震動の作用が津波避難に及ぼす影響
}

\author{
秦 吉弥 1 - 湊 文博 2 - 常田 賢一 3 - 青木 伸一 4 ・鍬田 泰子 5 - 小山 真紀 6 \\ 1 正会員 大阪大学助教 大学院工学研究科（†565-0871 大阪府吹田市山田丘2-1） \\ E-mail: hata@civil.eng.osaka-u.ac.jp \\ 2 学生会員 大阪大学学生 大学院工学研究科（广565-0871 大阪府吹田市山田丘2-1） \\ E-mail: fminato@civil.eng.osaka-u.ac.jp \\ 3 フェロー会員 大阪大学教授 大学院工学研究科（干565-0871 大阪府吹田市山田丘2-1） \\ E-mail: tokida@civil.eng.osaka-u.ac.jp \\ 4 フェロー会員 大阪大学教授 大学院工学研究科（率565-0871 大阪府吹田市山田丘2-1） \\ E-mail: aoki@civil.eng.osaka-u.ac.jp \\ 5 正会員 神戸大学准教授 大学院工学研究科（广657-8501 兵庫県神戸市灘区六甲台町1） \\ E-mail: kuwata@kobe-u.ac.jp \\ 6 正会員 岐阜大学准教授 岐阜大学流域圈科学研究センター（†501-1193 岐阜県岐阜市柳戸1-1) \\ E-mail: maki_k@gifu-u.ac.jp
}

\begin{abstract}
静岡県沿岸域は，南海卜ラフ巨大地震において非常に大きな強震動の作用だけでなく巨大津波の来襲が 予想されており, 強震動作用中の避難困難時間と強震動作用後の避難所要時間をそれぞれ評価しておくこ とは重要である。そこで本稿では，まず，静岡県沿岸域の既存強震観測点を対象にした南海トラフ巨大地 震による強震動予測を実施し, 避難困難時間を評価した。次に, 強震動予測地点から周辺の避難所までを 対象にした歩行計測実験を行うことで，避難所要時間を評価した。最後に，避難困難時間と避難所要時間 の関係性に基づいて, 静岡県沿岸域が有する津波避難パフォーマンスの現状に関して議論を行った.
\end{abstract}

Key Words : tsunami evacuation, strong motion estimation, walking experiment, time management

\section{1. はじめに}

静岡県沿岸域(図-1参照)は，近未来に発生が䀣念され ている南海トラフ巨大地震において巨大津波の来襲が予 想 1)されている. 一方で，南海トラフ巨大地震の想定震 源域の近傍に位置していることから(図-1参照)，非常に

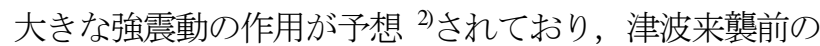
強震動の作用が住民等の津波避難行動に大きな影響を及 ぼすことも考えられる．強震動作用中に避難行動をとる ことが困難な時間(いわゆる避難困難時間)を評価してお くことは，当該地域における津波来襲時間から避難困難 時間ならびに避難所要時間をそれぞれ差し引いた避難余 裕時間を算定し，津波避蜼施設の新設に関する具体的な 根拠とする際などに有効引である.

この点に関して著者ほか ${ }^{4} は ，$ 駿河湾沿岸の相良地区 および松崎地区における既存強震観測点を対象に，南海 トラフ巨大地震による強震動作用中の避難困難時間の評 価を行い，評価手法の違いが避難困難時間の算定結果に
及ぼす影響について定量的な検討を行っている。しかし ながら, 検討対象とした地域が駿河湾沿岸の僅か 2 地点 に留まっているだけでなく, 避難困難時間と避難所要時 間の関係性などについても言及されていない.

そこで本稿では，特別セッションの指定課題である 「静岡県沿岸域における海岸保全」を考える上で, 静岡 県沿岸域内において津波来襲予想地域 ${ }^{1}$ に位置している 既存強震観測点 (計 14 地点 : 図-2 参照) 対象に, 南海 トラフ巨大地震における強震動シミュレーションを実施 し，強震動の作用が津波避難に及ぼす影響について検討 を行うとともに，避難困難時間と避難所要時間の関係性 についても同時に言及した.

具体的には，まず，現地踏查の結果に基づいて対象と する既存強震観測点を選定し，選定地点における地盤震 動特性を評価した. 次に, 南海トラフ巨大地震を対象と した強震動シミュレーションを実施し, 選定した地点相 当に作用する強震動を予測するとともに，気象庁計測震 度ならびに避難困難時間についても同時に算定した。さ 
表-1 静岡県沿岸域における選定観測点と選定避難所の一覧

\begin{tabular}{c|l}
\hline 観測点コード & \multicolumn{1}{|c}{ 観測点名 } \\
\hline SMD & SK-net下田市東本郷（下田市役所） \\
MTZ & SK-net賀茂郡松崎町宮内（松崎町役場） \\
NIZ & SK-net賀茂郡西伊豆町仁科（西伊豆町役場） \\
TOI & SK-net伊豆市土肥（伊豆市土肥支所） \\
HDA & SK-net沼津市戸田（沼津市民空口事務所） \\
NMD & SK-net沼津市御幸町（沼津市役所） \\
TGU & 田子の浦-S（田子の浦港） \\
SMZ & 清水-S（清水港）（焼津市役所） \\
YID & SK-net焼津市本町） \\
SGR & SK-net牧之原市相良（牧之原市相良庁舎） \\
OMZ & 東京大学地震研究所御前崎（御前崎市下御前） \\
HMT & KiK-net浜松（遠州灘海浜公園） \\
MSK & SK-net浜松市西区舞阪町舞阪（舞阪総合事務所） \\
ARI & KiK-net新居（湖西市新居町新居） \\
\hline
\end{tabular}

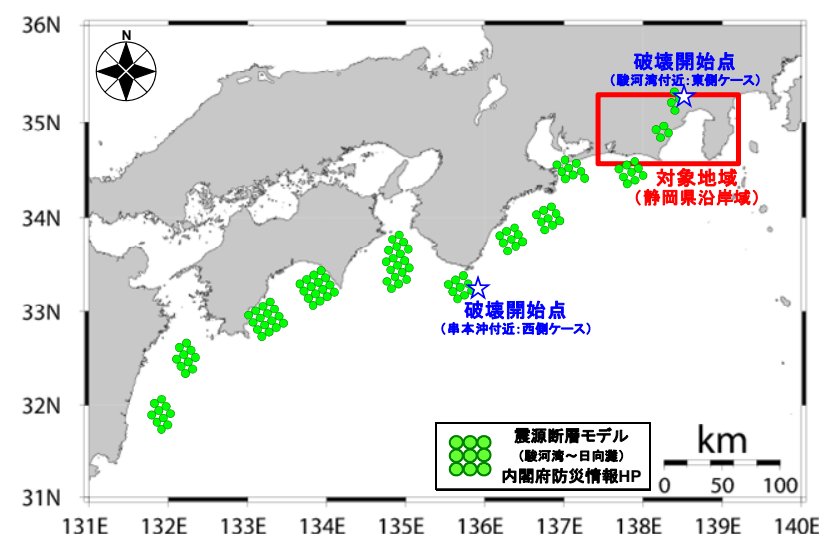

図-1 南海トラフ巨大地震の震源域と静岡県浻岸域

らに，強震動予測地点から周辺の指定避難場所までの所 要時間に関する歩行計測実験を行うことで，避難所要時 間を評価した。最後に，避難困難時間に対する気象庁計 測震度の関係性，および避難困難時間に対する避難所要 時間の関係性についてそれぞれ検討・考察を行うことで, 静岡県沿岸域が有する津波避難パフォーマンスの現状に 関して基礎的な検討を行った。

\section{2. 選定観測点におけるサイト増幅特性の評価}

本研究では，以下に示す条件を全て満足する南海トラ フ巨大地震の想定震源域近く・静岡県沿岸域内にある既 存強震観測点を机上検討により抽出した.

・南海トラフ巨大地震の発生直後に津波の早期来襲が 予想されている地域 ${ }^{11}$ に位置していること

・公的機関による既存の強震観測点であること

・2009年 8 月 11 日 5 時 7 分に発生した駿河湾を震源と する気象庁マグニチュード 6.5 の地震(以後， 2009 年 駿河湾の地震と呼ぶ(図-2 内に乞印で示すサイト位相

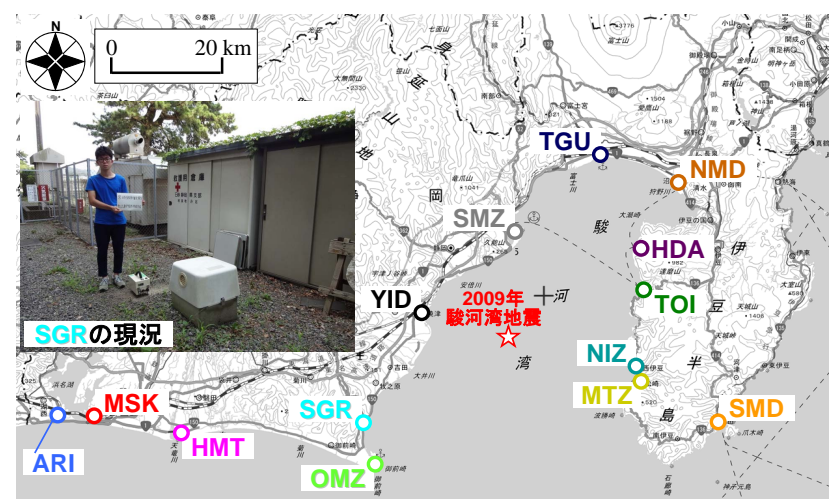

図-2 静岡県沿岸域における選定観測点の分布

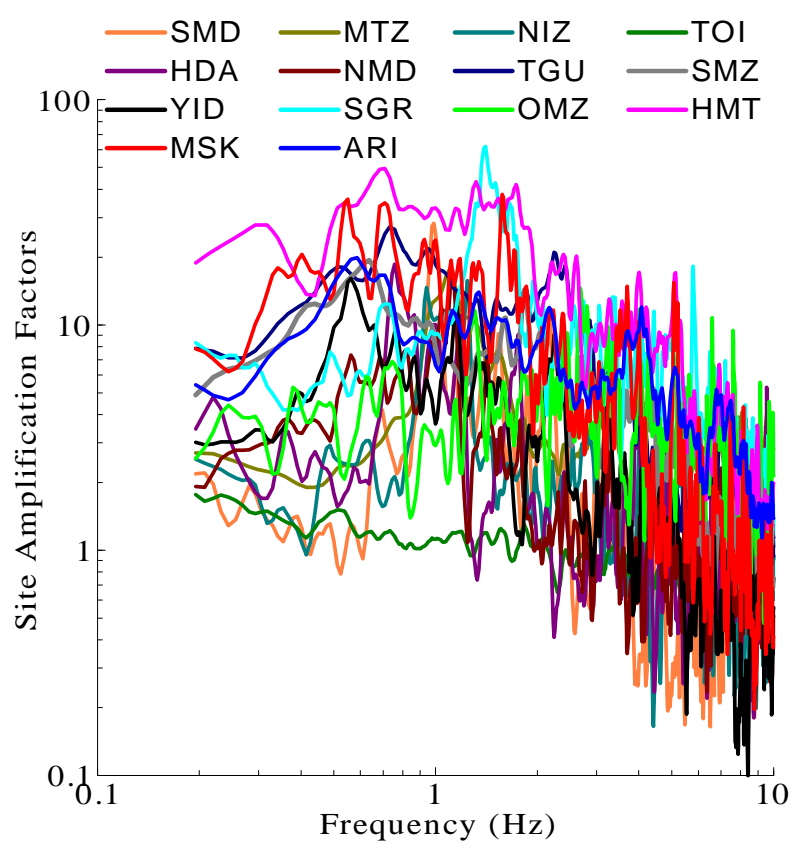

図-3 サイト増幅特性(地震基盤〜地表)の比較

特性評価地震))による記録が得られていること 上記の机上検討において抽出した既存強震観測点に対 して現地踏査(図-2の枠内写真の一例参照)を行い，特殊 な環境下 (例えば，当該地点相当において予想されてい る津波来襲高1)よりも現地踏査によって確認した観測点 設置の標高が局所的に高い地点など)にある観測点を適 宜除外した。その結果，図-2および表-1に示すとおり， 本稿において取り扱う静岡県沿岸沿いの既存強震観測点 (計14地点)を選定した(以後，選定観測点と呼ぶ).

図-3は，選定観測点におけるサイト増幅特性の比較で ある.ここに，本稿でのサイト増幅特性は，いずれも地 震基盤〜地表相当の地盤震動特性を表している. KiK-net 観測点であるHMTおよびARIについては，既存のもの ${ }^{5)}$ を転用した。一方で，HMTおよびARI以外の選定観測点 については，2009年駿河湾の地震による観測記録 (図-4 参照)に基づいて算定した。 具体的には，対象観測点と その周辺のK-NET観測点で同時に得られた2009年駿河湾 の地震による観測記録を対象に，伝播経路特性(6)7の違い を考慮したフーリエスペクトルの比率 (対象観測点 / K- 


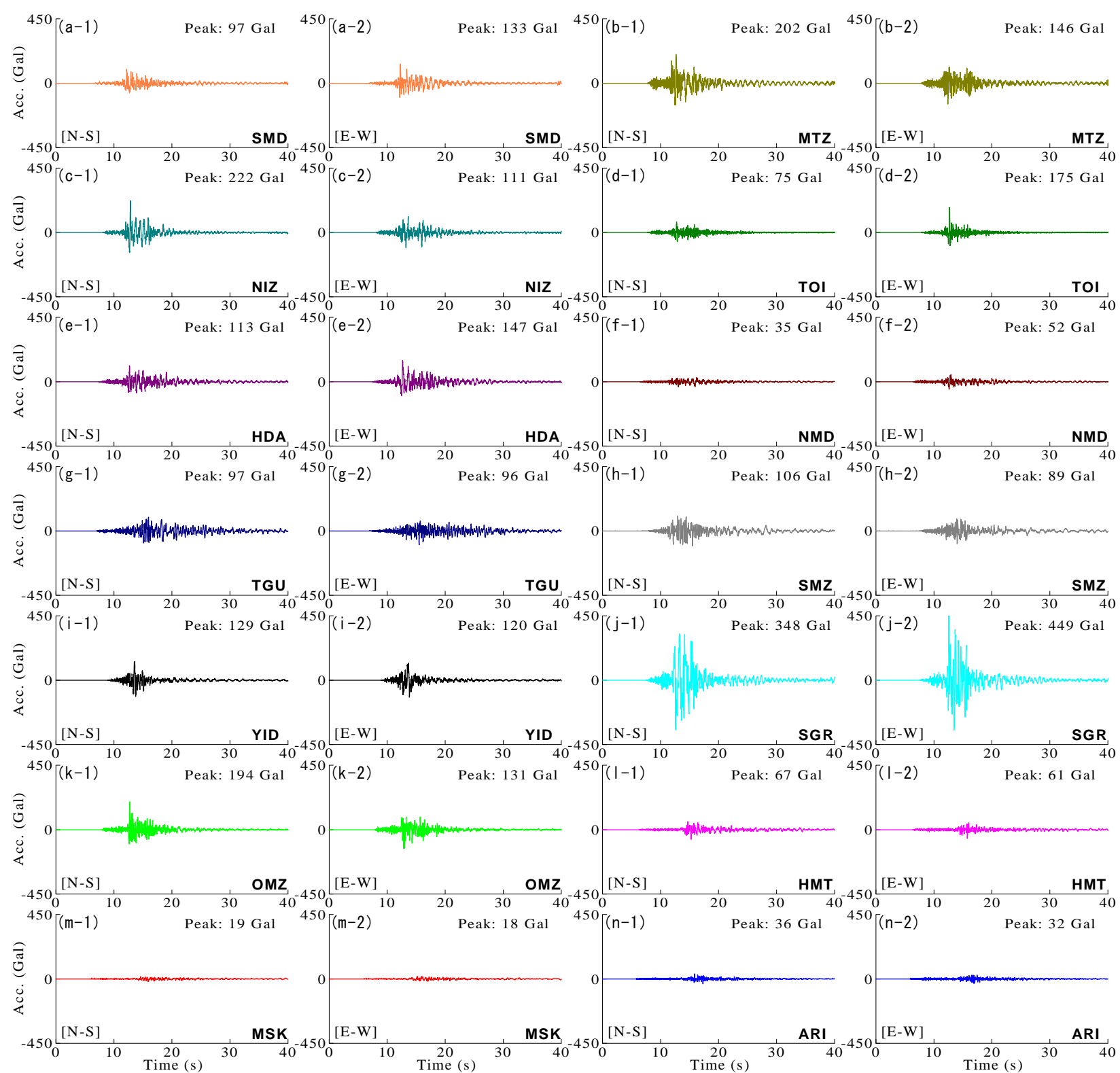

図-4 2009年駿河湾の地震における選定観測点での同時観測記録(サイト位相特性として採用した地震加速度波形)の比較

NET観測点)を計算し，この比率をK-NET観測点におけ る既存のサイト増幅特性らに掛け合わせることによって サイト増幅特性を算定した.

図-3に示すように, サイト増幅特性の特徵 (任意の周 波数帯における地震動の増幅割合，ピーク周波数，スペ クトル形状など)が選定観測点ごとに顕著な差異が見受 けられ，静岡県沿岸域における地盤震動特性は一様であ るとは言い難い，これは，南海トラフ巨大地震時におい て静岡県沿岸域に作用する強震動の特性にも大きな違い が生じる可能性が高いことを示唆するものである.

\section{3. 震源モデルと強震波形計算手法}

南海トラフ巨大地震による地震動の推定には, 内閣府 南海トラフの巨大地震モデル検討会”によるSMGAモデ
ル(基本ケース)を採用した．図-1に静岡県駿河湾〜宮崎 県日向灘のサブイベント (12個のSMGAで構成) と津波来 襲地域の位置関係を示寸．モデルパラメターの詳細につ いては，文献2)を参照されたい。 なお， $Q$ 值については, 佐藤・巽による推定值》を採用した，本稿では，この震 源モデルにおいて破壞開始点の位置を駿河湾 (以後，東 側ケースと呼ぶ)もしくは串本沖(以後，西側ケースと呼 ぶ)にそれぞれ配置4した(図-1参照)。

本研究では，経験的サイト増幅・位相特性を考慮した 強震波形計算手法8)を適用した。この方法では，まず式 (1)により統計的グリーン関数を生成する.

$$
A(f)=S(f) \cdot P(f) \cdot G(f) \cdot \frac{O(f)}{|O(f)|_{p}}
$$

ここに，A(f)は地表における統計的グリーン関数のフー リエ変換で複素数, $S(f)$ は小地震の震源スペクトルで実 


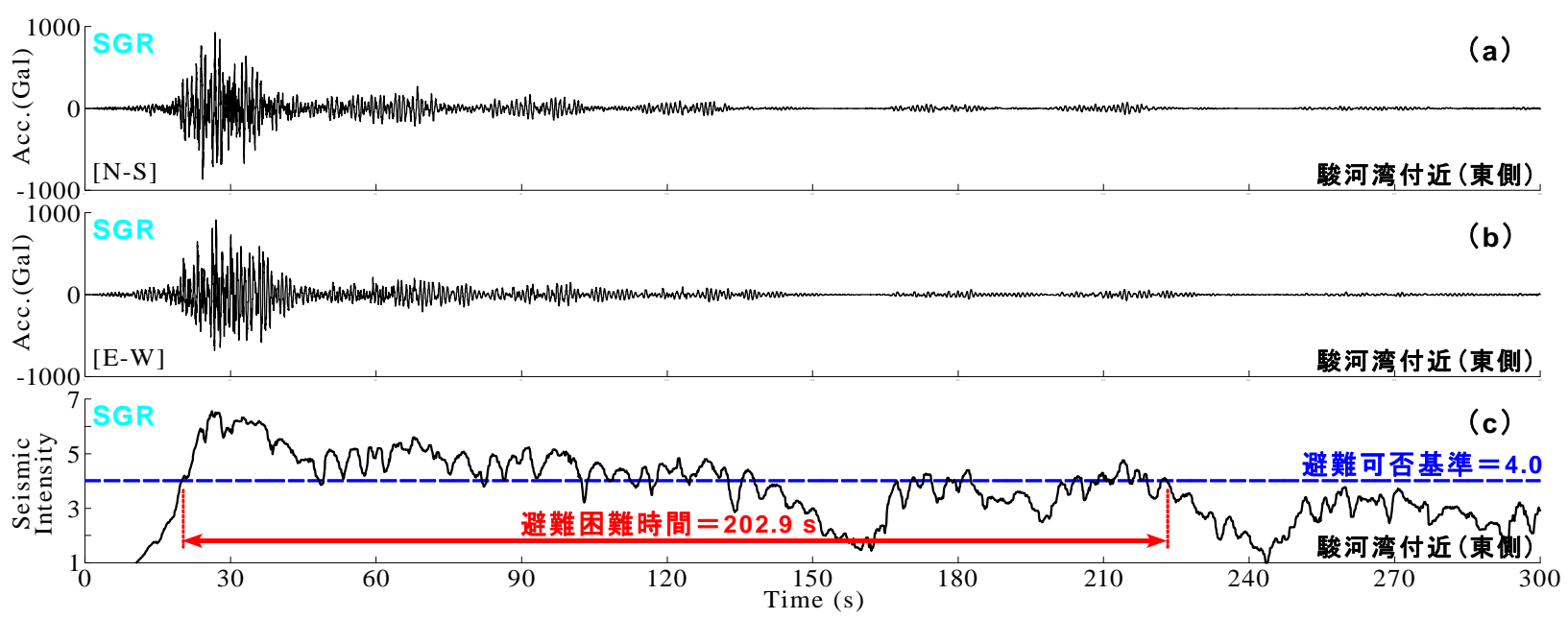

図-5 水平二成分の予測地震動（同図 (a), (b) 参照) に基づく避難困難時間の算定例（同図 (c) 参照)

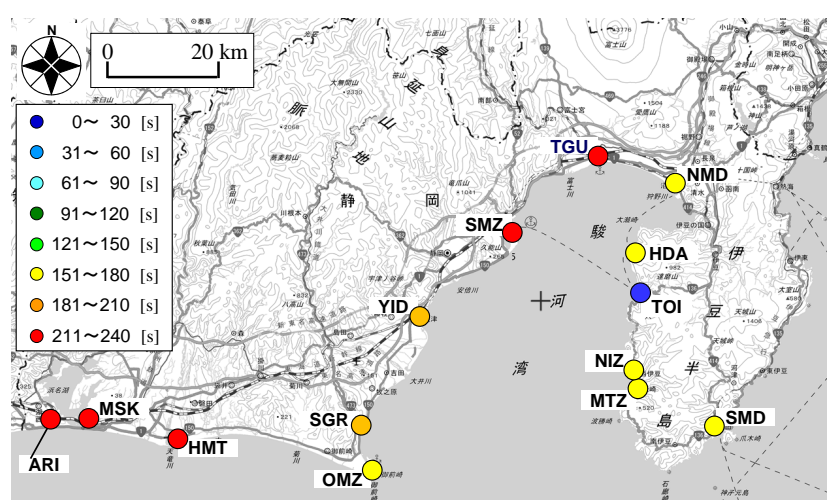

図-6＼cjkstart避難困難時間の分布（駿河湾ケース）

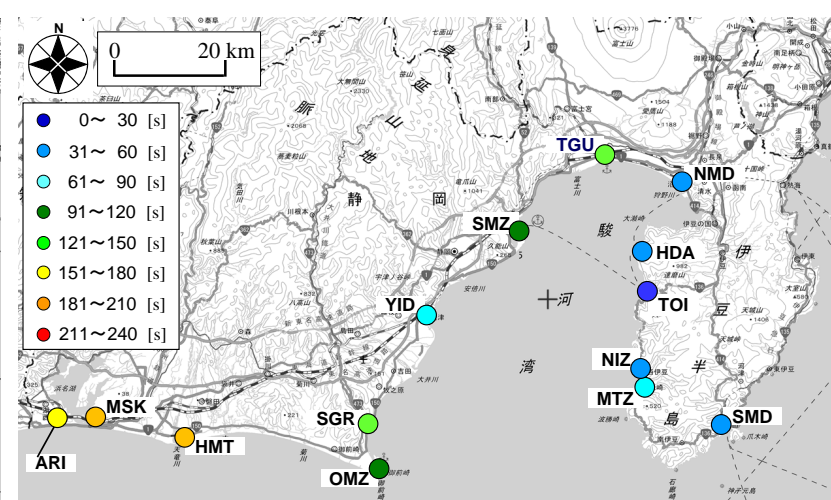

図-7＼cjkstart避難困難時間の分布（串本沖ケース）
数, $P(f)$ は伝播経路特性无で実数, $G(f)$ はサイト増幅特性 (図-3参照)で実数，O(f)は津波来襲地域での中小地震観 測記録のフーリエ変換で複素数, $|O(f)| p$ はその絶対值に 対してバンド幅 $0.05 \mathrm{~Hz}$ のParzen Windowを適用したもので ある，震源特性を計算する際，ラディエーション係数 ${ }^{6}$ としては，全方位への平均值である0.63を用いた。また， 地震動エネルギ一の水平二成分への分散を表す係数であ るPRTITN ${ }^{6}$ 水平二成分ともに0.71とした.

式(1)からわかるように，本手法では，統計的グリー ン関数のフーリエ振幅は震源特性・伝播経路特性・サイ 卜特性の積として求め, 統計的グリーン関数のフーリエ 位相としては，現地で得られた地震記録のフーリエ位相 を用いる。式(1)をフーリエ逆変換し，経験的グリーン 関数法と同様の重ね合わせを行うことで，大地震による 波形が求まる. なお, Parzen Window(式(1)において添字p で表示) は，因果性を満足する地震波を生成する目的で 用いられている 震観測記録のフーリエ変換 $O(f)$ )の取り扱いについては, 入射角およびback azimuthが各サブイベントとできるだけ 共通となるように(堆積層が地震動の位相に及ぼす影響 をより適切に考慮できるように)，2009年駿河湾の地震 によって選定観測点 (計14地点 : 図-2参照)において同時
に得られた地震波形(図-4参照)を東側ケースおよび西側 ケースにおいて共通採用した。 図-4に示すように，選定 観測点毎の波形形状に差異が確認できることから，予測 強震動の波形形状にも差異が生じる可能性が示唆される.

\section{4. 避難困難時間と気象庁計測震度の関係}

図-5(a),(b)には，強震動予測結果の一例として，東側 ケースにおけるSGRでの予測地震動 (水平動) の加速度 波形を示す。ここでは，SMGAモデルを震源モデルとし て採用しているため，一定の信頼性があると考えられる 地震動指標值として，気象庁計測震度および避難困難時 間9),10)をそれぞれ算定した。具体的には，水平二成分合 成による瞬間計測震度 ${ }^{9}$ の の時刻歴を計算し(図-5(c)の一 例参照), 時刻歴内での最大值を気象庁計測震度, 瞬間 計測震度が最初に4.0を上回り・最後に4.0を下回るまで (先行研究4),10)による知見を参考に設定)の連続時間を避 難困難時間とそれぞれ定義した。図-6および図-7には, 東側ケースおよび西側ケースにおける静岡県沿岸沿いで の強震動作用中の避難困難時間の分布を示す.

図-6および図-7に示すように，各選定観測点でのサイ 
卜増幅・位相特性の差異や南海トラフ巨大地震の発生シ ナリオ(破壊開始点)の差異などに起因して，避難困難時 間は静岡県沿岸沿いの選定観測点ごとに一様であるとは 言い難く，東側ケースではTGU, SMZ, HMT, MSK, ARIに おいて，西側ケースではHMT, MSKにおいてそれぞれ避 難困難時間が比較的長くなっている. よって, 静岡県沿 岸沿いにおける各々の選定観測点が位置する地域が有す る津波避難パフォーマンスには，有意な差異があること が示唆される. 特に, HMTおよびMSK付近では, 南海 トラフ巨大地震の発生シナリオに関わらず, 津波避難に 関するリスクが比較的高いことが読み取れる. 一方で, 図-6と図-7を比較すると，西側ケース(図-7参照)よりも 東側ケース (図-6参照)のほうが，静岡県沿岸沿いの避難 困難時間が全体的に長く算定される傾向にある.

図-8(左)は，予測強震動に基づく避難困難時間（図-6お よび図-7参照にに対応する気象庁計測震度の関係である. 図-8(左) に示すとおり，避難困難時間が長くなるにつれ て気象庁計測震度が大きくなる傾向が読み取れる. 気象 庁計測震度は構造物等の被荻程度に関する評価指標の一 種であるため，この傾向は，静岡県沿岸域において強震 動作用中の避難困難時間が比較的長時間に及ぶ場合, 構 造物等の被災が強震動作用後の津波避難行動にも大きな 影響を及ぼす可能性が高いことを示唆するものである.

\section{5. 避難困難時間と避難所要時間の関係}

静岡県沿岸沿いの選定観測点 (津波来襲予想地域の中
心付近に位置しており，対象地域を概祆代表していると 考えられる地点) から周辺の指定避難場所までの歩行時 間(避難所要時間)に関する計測実験を行った。 その際,

表-1 に示すように，地方自治体における津波八ザード マップ等を参考に，津波来襲予想高に対して十分な余裕 を有する避難場所を，選定観測点ごとにそれぞれ選定し た(以後, 選定避難場所と呼ぶ)。歩行計測実験は, 本稿 の第一著者(35 歳男性)を被験者とし, 被験者が通常通 りの歩行を行った. なお, 選定観測点から周辺の選定避 難場所までの歩行計測実験を 10 回繰返し，その平均を 避難所要時間として採用した. その結果, 計 140 回に及 ぶ平均歩行速度として $72 \mathrm{~m} / \mathrm{min}$ が得られた。

図-8(右)は，予測強震動に基づく避蜼困難時間（図-6お よび図-7参照)に対応する避難所要時間の関係である.

図-8(右)に示寸とおり, 避難所要時間に対寸る避難困難 時間の割合 (避難困難時間: 避難所要時間)に着目寸ると, 概ね1:0.5ならびに1:1以下となる選定観測点は8/28(29\%)， および概ね1:2以下となる選定観測点は19/28(68\%) となっ ており, 静岡県沿岸域では避難所要時間に対して避難困 難時間が一定の割合を占めていることが読み取れる.

ここに，津波避難困難区域の設定等 ${ }^{11)}$ では，避難所要 時間は地域特性が考慮された変動の時間, 避難困難時間 は地域特性が考慮されていない一律の時間としてそれぞ れ取り扱われているのが現状である。しかしながら，図 -8(左)および図-8(右)による知見を踏まえれば，静岡県 沿岸域における津波防災(海岸保全)を考える上で, 避難 所要時間だけでなく避難困難時間についても対象とする 地域特性を考慮して適切に設定する必要性が示唆される.

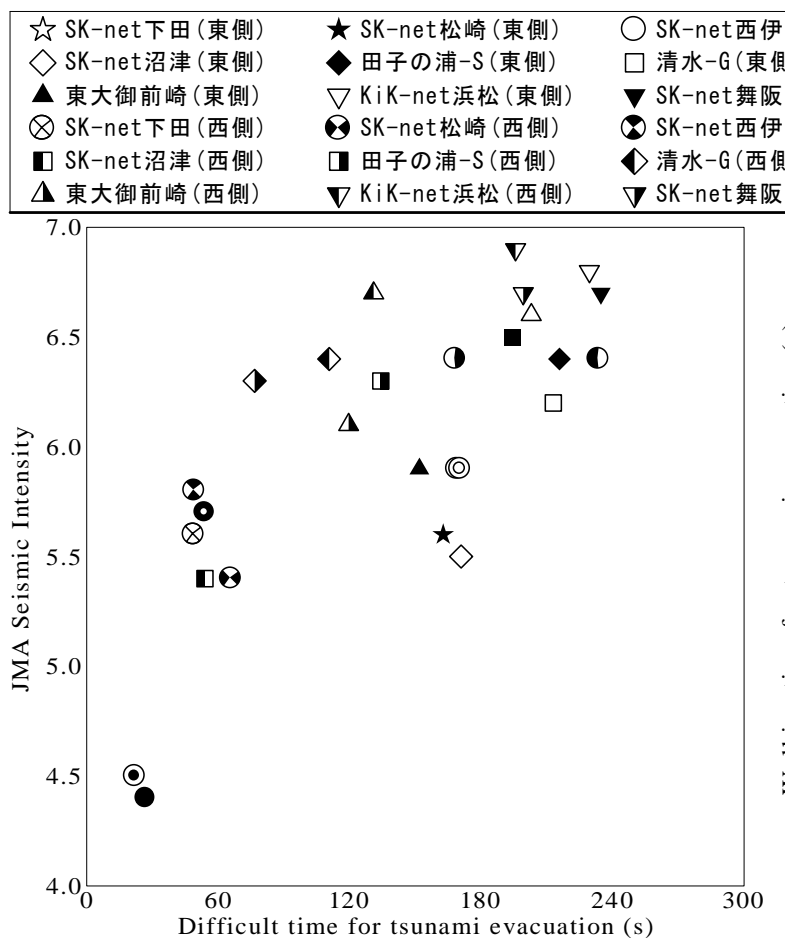

\begin{tabular}{|c|c|c|}
\hline 豆 (東側) & SK-net土肥 (東側) & (2) SK-net戸田 (東側) \\
\hline 則) & SK-net焼津 (東側) & $\triangle$ SK-net相良 (東側) \\
\hline （東側） & KiK-net新居 (東側) & \\
\hline 豆 (西側) & ( SK-net土肥 (西側) & ○ SK-net戸田 (西側) \\
\hline 5 (西/明) & $\checkmark$ SK-net焼津 (西側) & $\Delta S K-n e t$ 相良 (西側) \\
\hline 反（西側） & (1 KiK-net新居（西側） & \\
\hline
\end{tabular}

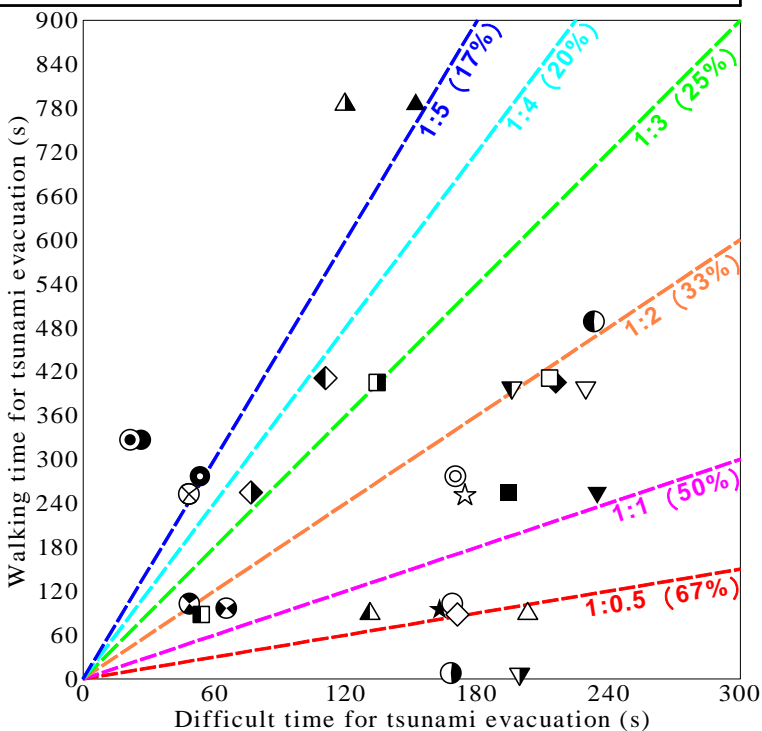

図-8 避難困難時間と気象庁計測震度の関係（同図 $($ 左 $)$ ），避難困難時間と避難所要時間の関係 (同図 $($ 右 $)$ ) 


\section{6. まとめ}

本研究では, 静岡県沿岸域の津波来襲予想地域を対象 に，南海トラフ巨大地震における強震動作用中の避難困 難時間と強震動作用後の避難所要時間をそれぞれ評価し

た．以下に得られた知見を示す。

(1) 南海トラフ巨大地震において静岡県沿岸域の津波来 襲予想地域に作用寸る強震動の特性(気象庁計測震 度や避難困難時間) は一様と見なすことはできない。

(2) 避難困難時間と気象庁計測震度には概衫正の相関が 確認できることから，避難困難時間が比較的長時間 に及ぶ場合, 構造物等の被災が強震動作用後の避難 行動にも大きな影響を及ぼす可能性が高い.

(3) 避難所要時間に対して避難困難時間は一定の割合を 占めていることから，静岡県沿岸域における津波防 災を考える上で，避難所要時間だけでなく避難困難 時間についても対象とする地域の特性を考慮して適 切に設定する必要性が高い.

今後は，本稿で取り扱っていない津波来襲予想時間も 含めたより詳細な検討を実施することで，静岡県沿岸域 における津波防災に貢献していきたいと考えている.

謝辞 : 本研究では, 首都圈強震動総合ネットワーク (静 岡県 SK-net), 港湾地域強震観測, 東京大学地震研究所, (国研) 防災科学技術研究所 K-NET/KiK-net による地震観 測波形デー夕を使用しました。 公益財団法人鹿島学術振 興財団 2015 年度研究助成「地域特性を考慮した津波避 難困難区域の抽出～強震動予測と歩行実験によるハイブ リッド評価〜」の一部を使用しました.

\section{参考文献}

1) 南海トラフの巨大地震モデル検討会 : 南海トラフの 巨大地震モデル検討会 (第二次報告)，津波断層モデ ル編一津波断層モデルと津波高・浸水域等について
一, 内閣府 HP, 2012. (last accessed: 2016/03/27)

2) 南海トラフの巨大地震モデル検討会 : 南海トラフの 巨大地震モデル検討会 (第二次報告), 強震断層モデ ル編一強震断層モデルと震度分布について一, 内閣 府 HP, 2012. (last accessed: 2016/03/27)

3) 秦吉弥, 湊文博, 常田賢一, 小山真紀, 鍬田泰子, 山田雅行 : 強震動予測および歩行実験に基づく津波 避難困難地域の評価一和歌山県串本町を例として一, 土木学会論文集 B3, Vol.71, No.2, pp.I_671-676, 2015.

4) 秦吉弥, 湊文博, 山田雅行, 鍬田泰子, 小山真紀, 中嶋唯貴, 常田賢一: 強震動作用中の津波避難困難 時間に関する評価精度とその向上策一南海トラフ巨 大地震における駿河湾沿岸域を対象として一，構造 工学論文集, 土木学会, Vol.62A, 2016.

5) 野津厚, 長尾毅, 山田雅行 : スペクトルインバージ ヨンに基づく全国の強震観測地点におけるサイト増 幅特性とこれを利用した強震動評価事例, 日本地震 工学会論文集，Vol.7, No.2, pp.215-234, 2007.

6) Boore, D. M.: Stochastic simulation of high-frequency ground motions based on seismological models of the radiated spectra, Bulletin of the Seismological Society of America, Vol.73, No.6A, pp.1865-1894, 1983.

7) 佐藤智美, 巽誉樹 : 全国の強震記録に基づく内陸地 震と海溝性地震の震源・伝播・サイト特性, 日本建 築学会構造系論文集, No.556, pp.15-24, 2002.

8) 野津厚, 長尾毅, 山田雅行 : 経験的サイト増幅・位 相特性を考慮した強震動評価手法の改良一因果性を 満足する地震波の生成一, 土木学会論文集 A, Vol.65, No.3, pp.808-813, 2009.

9) Kuwata, Y. and Takada, S.: Instantaneous instrumental seismic intensity and evacuation, Journal of Natural Disaster Science, Vol.24, No.1, pp.35-42, 2002.

10) 鍬田泰子, 齊藤栄 : 瞬間計測震度を用いた摇れ最中 の避難行動可能時間の定量化, 日本地震工学会論文 集, Vol.10, No.5, pp.52-65, 2010.

11) 例えば, 稲田健二 : 和歌山県の津波避難困難地域と 津波対策について, 平成 27 年度近畿地方整備局研究 発表会論文集，防災・保全部門 No.11，2015.

(2016.2.4受付)

\title{
EFFECTS OF ESTIMATED STRONG MOTION ON TSUNAMI EVACUATION IN COASTAL AREAS, SHIZUOKA PREFECTURE, JAPAN, DURING A SCENARIO EARTHQUAKE WITH $M_{\mathrm{W}} 9.0$ ALONG THE NANKAI TROUGH
}

\author{
Yoshiya HATA, Fumihiro MINATO, Ken-ichi TOKIDA, \\ Shin-ichi AOKI, Yasuko KUWATA and Maki KOYAMA
}

During a scenario earthquake with $M_{\mathrm{W}} 9.0$ along the Nankai Trough, not only strong motion but also huge tsunami is predicted in Shizuoka Prefecture, Japan. In this study, first, seismic waveforms at station sites for ground motion observation in the coastal area were estimated based on the SMGA models considering local site effects. Using non-evacuation time based on the time history of instrumental seismic intensity, the effect of the estimated strong motion on tsunami evacuation was then discussed. Finally, in order to evaluate evacuation time from the strong motion estimation sites to designated refuge places, walking experiments were carried out. The constructed relationship between the evacuation time and the non-evacuation time will be useful for conventional seashore preservation in Shizuoka Prefecture. 